\title{
Peran Raden Fatah Dalam Islamisasi di Kesultanan Demak Tahun 1478-1518
}

\author{
Agus Susilo, Ratna Wulansari \\ Pendidikan Sejarah STKIP PGRI Lubuklinggau \\ Email: agussusilo4590@gmail.com
}

\begin{abstract}
Introduction : This scientific article is an article that discusses the Role of Raden Fatah in Islamization in the Demak Sultanate in 1478-1518. The background of this article tells how Raden Fatah was the founder of the Demak Sultanate and the first Sultan of Demak since its founding in 1478 M. Raden Fatah was a descendant of King Brawijaya V who was the ruler of the last Majapahit Kingdom of a Chinese princess. But Raden Fatah's childhood in Palembang was raised by his mother and his stepfather Aryo Damar.

Data Collection Method : In this research article, researchers used historical research methods. Historical research seeks to reveal historical facts in the past.

Analysis Data : The steps of this historical research include heuristics, criticism (external criticism and internal criticism), source verification, and historiography.

Results and Discussions : The results of this study were that in Islamizing Javanese land, especially Demak, Raden Fatah and the Walisongo built a Great Mosque of Demak. The aim is to bring Islam to the hearts of the people of Demak and its surroundings. Demak Sultanate is increasingly crowded with martyrdom from several regions in the archipelago and abroad because it has good ports and produce. The Demak Sultanate wanted to Islamize the entire land of Java. But the teachings of Islam still maintain tolerance in religion and daily life. Walisongo's role such as Sunan Kalijaga in Islamizing Javanese society through Wayang and Gamelan art was vital. Many Javanese people finally moved their hearts to embrace Islam.

Conclusions : The conclusions of this historical research are in the Islamization of the Raden Fatah Javanese community assisted by the Walisongo by promoting the element of local wisdom. Raden Fatah also maintains relations with Prabu Brawijaya V at all times of his own father. Islam developed rapidly in Demak and was able to spread in several regions of the archipelago.
\end{abstract}

Keywords: Raden Fatah, Islamization, Kingdom of Demak

\section{A. PENDAHULUAN}

Negara Indonesia merupakan negara kepulauan yang memiliki lautan samudera yang sangat luas. Apabila di tinjau dari letak secara geografis nusantara merupakan benua arkipelogis yang diperhitungkan betapa tidak, laut yang menjadi wilayah Republik Indonesia membentang sepanjang $81.000 \mathrm{~km}$ dan luasnya 3,9 juta per $\mathrm{km}^{2}$, yang di dalamnya berjajar pulau-pulau yang jumlahnya mencapai kurang lebih 17.508 
buah yang terdiri dari pulau besar maupun kecil. Pada zaman sebelumnya di masa Belanda maupun masa zaman Majapahit lautan sudah dimanfaatkan dalam rangka sebagai sarana untuk meningkatkan taraf kehidupan masyarakat baik dalam bidang ekonomi, sosial maupun budaya. Pelabuhan merupakan alat atau sarana penghubung dari pulau satu ke pulau yang lain sehingga banyak pelabuhan yang menurut sejarahnya dahulu merupakan pelabuhan besar yang kini telah terbengkalai dan terkesan tidak dihormati nilai-nilai sejarahnya. ${ }^{1}$

Salah satu ciri yang menonjol dari kota-kota tradisional, terutama di Jawa, adalah keberadaan keraton, alun-alun, masjid, pasar, dan tembok atau pagar keliling (benteng). Pada tataran budaya, kota tradisional ditandai antara lain penggunaan teknologi yang masih sederhana, pengguna ilmu pengetahuan yang terbatas, serta sistem produksi yang masih didominasikan oleh tenaga manusia dan tenaga hewan. Penggunaan ilmu pengetahuan yang terbatas menyebabkan proses pembangunan kotakota tradisional tidak jarang muncul pemikiran-pemikiran yang tidak rasional dan tidak bisa diterima dengan alam pikiran saat ini tentang alasan dibangunnya kota tersebut. Munculnya mitos-mitos dalam proses pendirian kota pada periode kota tradisional sebenarnya merupakan cerminan ketidakberdayaan pikiran manusia pada waktu itu untuk mengetahui situasi di sekeliling mereka dengan nalar yang rasional. Hampir semua lokasi pendirian kota pada awalnya merupakan kawasan kosong, hutan-hutan, atau tanah yang berawa-rawa. Pada waktu itu sangat jarang masyarakat Jawa yang menguasai ilmu bumi, ilmu geografi, geologi, ilmu pengairan, atau landasan ilmiah yang lain. Sehingga jalan keluar untuk mengetahui hal tersebut dengan melihat kondisi di sekeliling mereka menggunakan nalar yang tidak rasional (dalam konteks pikiran masa kini). ${ }^{2}$

Sosok pemimpin dalam perkembangan zaman merupakan gambaran sebuah realita kehidupan berbangsa dan bernegara yang meliputi seluruh aspek kehidupan, baik dalam aspek politik, sosial, agama, budaya, maupun ekonomi. Seorang pemimpin juga menjadi tolak ukur kemajuan sebuah peradaban bangsa dan negara. Pemimpin dianggap

\footnotetext{
${ }^{1}$ Pianto, Heru Arif, 2017. Keraton Demak Bintoro Membangun Tradisi Islam Maritim di Nusantara. Jurnal SOSIOHUMANIORA 3, 1. (April 2017): 18-26. https://junal.ustjogja.ac.id/index.php/sosio/article/view/1521

${ }^{2}$ Basundoro, Purnawan, 2012. Pengantar Sejarah Kota. Yogyakarta: Ombak.
} 
sebagai komando bagi rakyat-rakyatnya untuk menuju ke arah kemakmuran, kejayaan, kesejahteraan maupun ke arah keterpurukan. Masa depan suatu kehidupan berbangsa dan bernegara bergantung kepada seorang pemimpin dan elemen-elemen pendukung negara. Suatu otoritas kekuasaan membutuhkan seorang pemimpin yang benar-benar mampu dan mumpuni dalam mengembangkan serta mempertahankan otoritas kekuasaan tersebut. Seperti halnya dengan kerajaan di Jawa, suatu kerajaan agar mampu bertahan dan mensejahterakan rakyatnya maka dibutuhkan seorang pemimpin yang hebat. Salah satunya adalah Kerajaan Demak yang telah mempunyai pemimpinpemimpin hebat sampai pernah maju dan berkembang pada masanya.

\section{B. TINJAUAN PUSTAKA}

Kekuasaan, kewenangan dan legitimasi merupakan terminologi yang sulit dipisahkan satu dengan yang lainnya. Kewenangan pada hakikatnya merupakan kekuasaan. Akan tetapi kekuasaan tidak selalu berupa kewenangan. Di antara keduanya, kekuasaan dan kewenangan, dibedakan dalam keabsahan. Kewenangan merupakan kekuasaan yang memiliki keabsahan, sedangkan kekuasaan tidak selalu memiliki keabsahan. Agar seseorang atau sekelompok orang yang memiliki kekuasaan sekaligus juga dapat memiliki kewenangan atas kekuasaan itu, maka yang bersangkutan dapat memperolehnya melalui berbagai sumber kewenangan yang ada. Melalui sumbersumber kewenangan tersebut yang bersangkutan dapat memperoleh keabsahan atas kekuasaan yang dimilikinya, dan berbagai macam cara dapat ditempuh untuk memperolehnya. Kedudukan kekuasaan yang didasari oleh tradisi itu adalah wajar dan patut untuk dihormati serta dipatuhi. Misalnya, berdasarkan tradisi yang diyakini masyarakat setempat bahwa anak seorang raja mempunyai hak untuk menggantikan kedudukan orang tuanya, dengan demikian anak raja tersebut mempunyai kekuasaan dan sekaligus kewenangan untuk menggantikan kedudukan orang tuanya. Wewenang kharismatik merupakan wewenang yang didasarkan pada kepercayaan anggota masyarakat pada kesaktian dan kekuatan mistik atau religius seorang pemimpin. ${ }^{3}$

Kerajaan Demak adalah Kerajaan Islam pertama di Pulau Jawa yang didirikan pada tahun 1478. Awal kekuasaan Kerajaan Demak dipimpin oleh Raden Fatah. Kepemimpinan Raden Fatah merupakan masa awal pertumbuhan Kerajaan Islam di

\footnotetext{
${ }^{3}$ Haryanto, 2010. Kekuasaan Elit Suatu Bahasa Pengantar. Yogyakarta: Pascasarjana (S2) Politik dan Otonomi Daerah Bekerja sama dengan Jurusan Ilmu Pemerintahan Fisipol UGM.
} 
Jawa. Ia berusaha mengislamkan masyarakat Jawa yang masih beragama HinduBuddha. Angkatan perang Demak mulai dibentuk sebagai penjaga dan pengayom negara serta untuk mewujudkan cita-cita menyebarkan agama Islam yang telah dirintis oleh Walisongo. Strategi Raden Fatah gagal dalam ekspedisi melawan Portugis, kemudian perjuangannya dilanjutkan oleh puteranya yang bernama Adipati Unus (Pangeran Sabrang Lor). Ia menjadi pemimpin Kerajaan Demak selama 3 tahun dan melanjutkan misi Raden Fatah untuk melawan Portugis. Perlawanan yang dilancarkan oleh Adipati Unus melawan Portugis tidak berhasil sehingga pasukan tentara Islam Jawa mengalami kekalahan dan Adipati Unus melarikan diri ke Jepara. Pelarian ini dengan harapan menyusun rencana kembali dalam melakukan perlawanan terhadap Portugis di Malaka. ${ }^{4}$

Peran para ulama / wali sangat besar terhadap jalannya pemerintahan di Kesultanan Demak. Hal ini terlihat sejak pertama kali proses Islamisasi di Jawa Tengah dengan memposisikan Sultan Fatah pemuka di Glagahwangi Bintari Demak sekitar tahun 1468 M, sampai pengangkatan Sultan Fatah sebagai Sultan Demak pertama dan sultan-sultan penggantinya. Para ulama juga mengambil bagian dalam menentukan kebijakan pemerintah dan ikut bertanggung jawab atas keamanan dan kesejahteraan negara. Bahkan disebutkan bahwa para ulama juga ikut berperang sebagai panglima, pengatur siasat, dan penggerak massa. Hal ini dapat dimengerti mengingat Sultan Fatah seusia dan seangkatan dengan Sunan Bonang, Sunan Giri, Sunan Kudus, dan Sunan Kalijaga. Sikap toleransi yang dimiliki masyarakat Demak, memiliki arti dan pengaruh besar terhadap perkembangan dakwah Islam. Dakwah Islam dengan terbuka dan tanpa paksaan menyebabkan Islam dapat berkembang dengan pesat. Mereka bersedia menerima apa yang datang dari luar dengan tidak membuang sama sekali apa yang sudah dimiliki. Sehingga dalam waktu tidak terlalu lama, Sultan Fatah beserta Walisongo sebagai cermin kolaborasi ulama-umara memperoleh kesuksesan yang besar dan berhasil mengIslamkan masyarakat Demak bahkan masyarakat Jawa pada

\footnotetext{
${ }^{4}$ Darmawijaya, 2010. Kesultanan Islam Nusantara. Jakarta: Pustaka Al-Kautsar.
} 
umumnya yang pada masa itu masih memeluk kepercayaan lama seperti Hindu, Buddha, Animisme, dan lain-lain. ${ }^{5}$

\section{METODE PENELITIAN}

Penelitian ini menggunakan metode penelitian historis atau metode sejarah. Masalah teori dan metodologi sebagai bagian pokok ilmu sejarah mulai ditengahkan apabila penulisan sejarah tidak semata-mata bertujuan menceritakan kejadian tetapi bermaksud menerangkan kejadian itu dengan mengkaji sebab-sebabnya, kondisi lingkungannya, konteks sosial-kulturalnya, pendeknya, secara mendalam akan diadakan analisis tentang faktor-faktor kausal, kondisional, kontekstual, serta unsur-unsur yang merupakan komponen dan eksponen dari proses sejarah yang dikaji. ${ }^{6}$

Langkah-langkah yang harus ditempuh dalam penelitian historis, yaitu:

1) Heuristik

Heuristik merupakan proses mencari data serta mengumpulkan sumber-sumber ataupun data-data yang diperlukan, kegiatan ini difokuskan pada studi arsip dokumen, literatur ilmiah, majalah maupun internet berkenaan dengan artikel ilmiah.

2) Kritik

Kritik sumber merupakan kegiatan untuk menyeleksi sumber sejarah yang telah didapatkan. Proses kegiatan kritik melalui dua tahap. Tahap pertama disebut kritik ekstern, yaitu langkah yang diambil untuk memproses atau menyeleksi data yang diluar dari sumber-sumber sejarah yang didapatkan. Tahap kedua, disebut kritik intern, yaitu kegiatan proses seleksi terhadap inti dari sumber-sumber sejarah yang telah melewati kritik ekstern.

3) Interpretasi

Pada proses interpretasi sejarah, seorang peneliti harus berusaha mencapai pengertian faktor-faktor yang menyebabkan terjadinya peristiwa. Oleh karena itu,

\footnotetext{
${ }^{5}$ Farida, Umma, 2015. Islamisasi di Demak Abad XV M: Kolaborasi Dinamis Ulama Umara dalam Dakwah Islam di Demak. AT-TABSYIR: Jurnal Komunikasi Penyiaran Islam 3, 2 (Desember, 2015): 299318.https://moraref.kemenag.go.id/documents/article/97406410605864589

${ }^{6}$ Kartodirdjo, 2012. Pendekatan Ilmu Sosial Dalam Metodologi Sejarah. Yogyakarta: Ombak.
} 
peneliti memerlukan pengetahuan tentang masa lalu sehingga dapat mengetahui situasi pelaku, tindakan, dan tempat peristiwa itu. ${ }^{7}$

4) Historiografi

Historiografi merupakan tahapan terakhir dari kegiatan penelitian suatu sejarah yang menyampaikan sintesa yang diperoleh dalam bentuk karya sejarah. Penelitian sejarah oleh peneliti disajikan secara deskriptif-analitis, sistematis dan kronologis. ${ }^{8}$

\section{HASIL PEMBAHASAN}

\section{Sejarah Kerajaan Demak}

Demak adalah kesultanan Islam pertama di pulau Jawa. Kesultanan Demak didirikan oleh Raden Fatah. Ia adalah anak dari istri Prabu Brawijaya V, seorang mulimah keturunan Cina yang dihadiahkan kepada Ario Damar sebagai Adipati Palembang. Raden Fatah tumbuh dan dibesarkan di Palembang. Raden Fatah mendirikan Kesultanan Demak pada tahun 1478. Sebelum berdirinya Kesultanan Demak, di Jawa telah berkembang beberapa bandar niaga Islam, seperti Jepara, Tuban, dan Gresik, tetapi bandar-bandar niaga ini masih berada di bawah kekuasaan Majapahit. Demak merupakan wilayah yang dihadiahkan oleh Kertabumi Brawijaya V kepada anaknya yang bernama Sultan Fatah. Banyaknya sungai dan pantai yang berada di wilayah ini menjadikan Demak mampu berkembang karena didukung oleh para syah Bandar di Tuban, Gresik, dan Ampeldenta, juga para saudagar Islam, disamping potensi sumber daya alam yang melimpah. Menurut Rachmad dalam (Farida, 2015: 305), pada kurun waktu 1476-1478, Demak menjadi wilayah yang ramai dan pusat ilmu pengetahuan dan penyebaran agama Islam. Sejak dipegang Sultan Fatah sebagai penguasanya, Demak juga memiliki pelabuhan yang besar yang menjadi lalu lintas bagi para nelayan dan perdagangan, sampai akhirnya Kesultanan Demak menjadi Pusat Kerajaan Islam pertama di Jawa.

Pada masa mudanya Raden Fatah memperoleh pendidikan yan berlatar belakang kebangsawanan dan politik. 20 tahun lamanya ia hidup di istana Adipati Palembang. Setelah dewasa ia kembali ke Majapahit. Raden Fatah mendalami agama Islam bersama pemuda-pemuda lainnya, seperti Raden Paku (Sunan Giri), Makhdum Ibrahim (Sunan

\footnotetext{
${ }^{7}$ Abdurrahman, Dudung, 2011. Metodologi Penelitian Sejarah Islam. Jakarta: Logos Wacana Ilmu.

${ }^{8}$ Gottschalk, 2008. Mengerti Sejarah. Jakarta: UI Press.
} 
Bonang), dan Raden Kosim (Sunan Drajat). Setelah dinyatakan lulus, Raden Fatah dipercaya menjadi ulama dan membuat pemukiman di Bintara. Raden Fatah memerintah Kerajaan Demak sampai tahun 1518, dan mampu menjadikan Demak menjadi pusat penyebaran Islam di Jawa sejak pemerintahannya. Keberhasilan Raden Fatah dalam memperluas dan mempertahankan Kerajaannya dapat dilihat ketika beliau menaklukan Girindra Wardhana yang merebut tahta Majapahit (1478), sampai dapat menggambil alih kekuasaan Majapahit. Dalam bidang dakwah Islam dan pengembangannya, Raden Fatah mencoba menerapkan hukum Islam dalam berbagai aspek kehidupan. Meskipun demikian, ajaran Islam memiliki sifat yang toleransi dengan para umatnya. ${ }^{9}$

Sebagai Kerajaan Islam pertama di pulau Jawa, Kerajaan Demak sangat berperan besar dalam proses Islamisasi pada masa itu. Kerajaan Demak berkembang sebagai pusat perdagangan dan sebagai pusat penyebaran agama Islam. Wilayah kekuasaan Demak meliputi Jepara, Tuban, Sedayu Palembang, Jambi dan beberapa daerah di Kalimantan. Disamping itu, Kerajaan Demak juga memiliki pelabuhanpelabuhan penting seperti Jepara, Tuban, Sedayu, Jaratan dan Gresik yang berkembang menjadi pelabuhan transito (penghubung). Demak adalah Kesultanan Islam pertama di Pulau Jawa dengan pendiri Raden Fatah. Kesultanan Demak dapat menjadi Kerajaan Islam yang utuh di bawah kekuasaan Sultan dan dengan bimbingan para Wali. Perebutan kekuasaan tunggal di dunia perniagaan di Asia Tenggara berjalan terus dengan perluasan wilayah Islam dari pusat Demak, agama Islam memancar dari pusat Islam di Demak, Tuban, Giri, Ampel oleh perantauan murid-murid wali kemanapun juga. Dalam waktu singkat Demak dapat mengimbangi pengaruh Malaka dibidang pengiriman mubaligh disepanjang jalan niaga, justru karena pengaruh para wali. ${ }^{10}$

Munculnya Kerajaan Demak sebagai kerajaan Islam pertama di pulau Jawa menjadikan Kerajaan Demak sangat diperhitungkan dari berbagai sudut pandang. Untuk menjaga keberlangsungan Kerajaan Demak, kerajaan ini banyak didukung oleh para

\footnotetext{
${ }^{9}$ Yogyanto, R. Nurcahyo, 2017. Peran Raden Fatah Dalam Mengembangkan Agama Islam Di Demak Tahun 1478-1518. Yogyakarta: FKIP Pendidikan Sejarah UPY.

${ }^{10}$ Ngationo, Ana, 2018. Peranan Raden Fatah Dalam Mengembangkan Kerajaan Demak Pada Tahun 1478-1518. Jurnal Kalpataru 4, 1 (Juli 2018): 17-28.https://jurnal.univpgripalembang.ac.id/index.php/kalpa/article/view/2445
} 
sunan / walisongo. Raja Demak pertama, Raden Fatah sebagai pendiri Kerajaan berusaha untuk menguasai jalur perdagangan penting di kepulauan Nusantara, Raja mengutus anaknya, Adipati Unus, untuk memimpin penaklukan Palembang dan Malaka, tujuannya untuk menguasai kedua pelabuhan yang ramai dikunjungi pedagangpedagang dari Asia maupun Nusantara. Selain itu, raja juga bertujuan menjaga agar perdagangan beras dan rempah-rempah di kepulauan Nusantara, yang dikuasai Demak, tidak terusik. Kepercayaan yang diberikan kepada Adipati Unus merupakan salah satu bentuk politik dinasti, ketika Demak sedang mengembangkan kekuasaannya. Bagaimanapun Adipati Unus akan mendukung kekuasaan ayahnya, yang suatu saat akan digantikannya. Selain memerluas wilayah kekuasaannya, Kerajaan Demak juga melakukan penyebaran agama Islam dengan bantuan para Walisongo. Peran Walisongo sangat vital dalam penyebaran Islam di pulau Jawa. Selain membantu penyebaran agama Islam, para Walisongo juga membantu dalam pemerintahan. Beberapa daerah taklukan Kerajaan Demak juga tidak lepas dari peran Walisongo. ${ }^{11}$

Kesultanan Demak Bintoro menjadi kerajaan besar dan terkenal baik di wilayah nusantara maupun di luar negeri dan pada waktu itu pula ajaran Islam di pulau Jawa berkembang dengan pesat. Hal itu tentunya tidak hanya dilakukan oleh para pejabat Kesultanan saja, akan tetapi yang berperan penting dalam penyebaran agama Islam ini adalah para wali/sunan. Mereka para sunan di angkat menjadi penasehat Kesultanan yang selalu melakukan dakwah dan memberikan pemikiran-pemikiran terhadap para pejabat Kesultanan termasuk Raden Fatah. Para wali yang tergabung dalam majelis ini berjumlah Sembilan orang dan oleh sebab itu di sebut Wali Songo. Untuk memudahkan penyebaran agama Islam, para wali memerlukan sarana. Untuk itu mereka para wali punya inisiatif untuk membangun masjid untuk memudahkan dalam pelaksanaan dakwahnya. Masjid yang dibangun itu dikenal dengan Masjid Agung Demak yang terkenal dengan salah satu tiang utamanya yang terbuat dari pecahan-pecahan kayu yang di sebut "Soko Tatal". Sejak dibangun Masjid Agung Demak itu kehidupan Islam semakin meningkat. Para wali selalu mengadakan musyawarah untuk menyelesaikan

\footnotetext{
${ }^{11}$ Lapian, A.B, 2010. Pelayaran dan Perniagaan Nusantara, Abad Ke-16 dan 17. Jakarta: Komunitas Bambu.
} 
segala urusan baik urusan agama maupun urusan pemerintahan di Masjid Agung Demak tersebut. ${ }^{12}$

\section{Islamisasi Masyarakat oleh Raden Fatah Tahun 1478 - 1518}

Seorang pemimpin mempunyai hak dan kewajiban. Hak dan kewajiban pemimpin mengarahkan ke sikap idealis yang dikehendaki. Sikap idealis seorang pemimpin melahirkan aturan, hukum, dan kebijakan dalam mengatur dan mendidik rakyatnya. Namun, tidak menafikan bahkan seorang pemimpin tentunya mempunyai idola atau tokoh yang dikagumi karena tindakan maupun pola kepemimpinannya sehingga ia berinisiatif untuk menirunya. Pada saat kepemimpinan Raden Fatah sebagai Sultan pertama Kerajaan Demak yang masih berdiri Kerajaan Hindu Majapahit, sebagian masyarakatnya juga masih beragama Hindu dan Buddha. Usaha demi usaha dilakukan oleh Raden Fatah untuk mengIslamkan masyarakat Demak dan Jawa secara keseluruhan, tanpa terkecuali Majapahit. Meskipun perjuangannya juga dilanda penghambat unsur-unsur agama lama, namun dengan bantuan para Walisongo semua halangan menjadi lebih ringan. Selain mengIslamkan Jawa, Raden Fatah juga berperang melawan Portugis di Malaka yang ingin memperluas wilayahnya sampai pulau Jawa. ${ }^{13}$

Kemauan dan kemampuan untuk berempati dengan jalan membuka diri untuk mau mengerti budaya orang lain. Bersikap empati berarti menanamkan rasa toleransi yang tinggi terhadap perbedaan latar belakang budaya. Sikap toleransi ini juga akan ditangkap oleh orang lain sebagai suatu penghargaan yang menumbuhkan simpati. Kemampuan untuk menerjemahkan proses komunikasi dari hambatan menjadi kekuatan budaya yang akan melahirkan kepercayaan diri, bahwa keterbukaan akan membawa manfaat positif ketimbang prasangka negatif. Dalam hal percaya diri berarti mempunyai kemampuan untuk menunjukkan identitas budaya secara apa adanya tidak berusaha memuji diri sendiri atau merendahkan budaya lain. Kemampuan memberi petunjuk bagi setiap orang dalam berhubungan dengan orang asing. Untuk menumbuhkan kepercayaan diri dalam komunikasi multikultural, beberapa cara lain yang dapat digunakan adalah dengan kesediaan melibatkan diri dalam kegiatan yang tidak

12 Pianto, Heru Arif, 2017. Keraton Demak Bintoro Membangun Tradisi Islam Maritim di Nusantara. Jurnal SOSIOHUMANIORA $\quad 3, \quad 1 . \quad$ (April $\quad 2017$ ): https://junal.ustjogja.ac.id/index.php/sosio/article/view/1521

13 Afifah, Nurul, 2018. Kepemimpinan Sultan Trenggana di Kerajaan Demak 1521-1546 Ditinjau Dengan Konsep Kepemimpinan Jawa HASTA BRATA. Yogyakarta: SKI UIN Sunan Kalijaga. 
bertentangan dengan prinsip-prinsip hidup peserta komunikasi. Mengembangkan komunikasi multikultural, berarti membangun satu jembatan emas yang sekiranya berguna menyambungkan dua sisi tebing yang dipisahkan oleh jurang, yaitu jurang sosialkultural. Jurang sosio-kultural tersebut berupa perbedaan ras, etnik, budaya dan tingkat kemajuan sosial ekonomi masyarakat yang tersebar di seluruh pelosok tanah air dari pusat kota sampai daerah terpencil sekalipun. ${ }^{14}$

Sultan pertama Kerajaan Demak adalah Raden Fatah. Ia bergelar Sultan Alam Akbar al Patah. Raden Patah adalah putra Raja Kertabumi (Brawijaya V) dari Majapahit dengan putri Cina. Setelah Demak menjadi kuat dan ketika Majapahit dipegang oleh Girindrawarna, pada tahun 1500 Raden Patah melepaskan diri dari kekuasaan Majapahit. Dengan dibantu oleh wali, Raden Patah kemudian memproklamasikan berdirinya Kerajaan Islam yang terkenal dengan sebutan Kesultanan Demak. Kerajaan ini merupakan kerajaan Islam pertama di Pulau Jawa. Di bawah pimpinan raja dan dibaritu oleh para wali, Demak berkembang menjadi pusat penyebaran agarna Islam yang sangat penting. Tahun 1511 Malaka jatuh ke tangan Portugis. Kejatuhan Malaka tersebut menjadikan Demak menjadi semakin penting peranannya sebagai pusat penyebaran agama Islam. Dibantu para ulama, Raden Patah mendirikan Kerajaan Demak, kerajaan Islam pertama di Pulau Jawa. Dalam waktu singkat, Demak berkembang menjadi kerajaan besar. Dalam pengembangan agama Islam, Demak berperan penting. Pada waktu itu Demak menjadi pusat penyebaran agama Islam. Penyebar agama Islam dengan sebutan wali. Sebagai tempat beribadah dan pusat kegiatan agama para wali mendirikan Masjid di Demak. ${ }^{15}$

Sebelum menjadi Kesultanan Demak merupakan sebuah Kadipaten di bawah kekuasan Majapahit. Demak sendiri saat itu lebih dikenal dengan nama Bintara atau Gelagah Wangi. Kadipaten Demak yang dipimpin oleh Raden Fatah yang merupakan anak dari Brawijaya yang merupakan Raja Majapahit terakhir. Pada tahun 1479, Raden Fatah meresmikan Masjid Agung Demak sebagai pusat pemerintahan. Raden Fatah pula memperkenalkan pemakaian Solakantara sebagai kitab Undang-Undang Kerajaan. Terhadap agama lain, Raden Fatah memiliki toleransi yang tinggi. Masjid Demak

\footnotetext{
${ }^{14}$ Purwasito, Andrik, 2015. Komunikasi Multikultural. Yogyakarta: Pustaka Pelajar.

${ }^{15}$ Yogyanto, R. Nurcahyo, 2017. Peran Raden Fatah Dalam Mengembangkan Agama Islam Di Demak Tahun 1478-1518. Yogyakarta: FKIP Pendidikan Sejarah UPY.
} 
dijadikan tempat pertemuan untuk belajar agama. Pada masanya, para wali seperti Sunan Kalijaga, Sunan Kudus, Sunan Bonang juga sering berkumpul di Masjid Demak. Masjid Demak didirikan pada masa kepemimpinan Raden Fatah. Kemudian dibangun kembali pada masa pemerintahan Sultan Trenggono. Pembangunan Masjid Demak dipimpin oleh Sunan Kalijaga. Salah satu tiang utama Masjid Demak terbuat dari pecahan kayu yang disebut dengan Soko Tatal. Soko Tatal berarti dari tatal. Tatal merupakan serpihan-serpihan kecil yang biasanya didapat dari bekas gergaji atau bekas pahatan. Arsitektur Masjid Demak merupakan wujud akulturasi kebudayaan Hindu dengan kebudayaan Islam. ${ }^{16}$

Sangat penting keberadaan Masjid Agung Demak dalam alam pikiran orang Jawa Islam. Selain itu posisi kota Negara Islam Demak menjadi kota Islam pertama di Jawa Tengah yang kemudian dikenal sebagai kota Negara Keraton Demak Bintara. Adanya negara Islam Demak ini menjadi pusat perdagangan dan lalu lintas. Banyak mereka para pedagang Islam berkumpul dan singgah ke Demak ini, hal ini tidak lepas karena keberadaan para wali yang mempunyai akhlak yang mulia dan sudah terkenal di kalangan masyarakat luas. Kecerdikan para wali dalam menyebarkan ajaran Islam ini tidak perlu diragukan lagi. Pada masa itu masyarakat yang masih beragama Hindu, Buddha, animisme maupun dinamisme tidak serta merta dipaksa masuk Islam begitu saja, akan tetapi mereka para wali menggunakan cara atau trik tersendiri dalam berdakwah. Diantaranya dengan cara menggunakan seni dan budaya yang tentunya sudah menjadi tradisi dari kalangan masyarakat muslim.

Ajaran dengan menggunakan seni budaya ini seperti yang telah dilakukan oleh Sunan Kalijaga pada waktu peresmian Masjid Agung Demak. Dalam peresmian itu Sunan Kalijaga mengadakan pentas wayang kulit semalam suntuk, hanya saja dalam cerita atau lakon pewayangan itu Sunan Kalijaga menyampaikan ajaran-ajaran Islam. Sedangkan lakon pada pertunjukkan wayang itu adalah "Bima Suci". Yang lebih unik pertunjukkan itu siapapun boleh datang dan menyaksikan asalkan mereka dapat membeli tiketnya. Tiket yang ditetapkan oleh Sunan Kalijaga bukan dibeli pakai uang atau harta benda yang lainnya, melainkan hanya "mengucapkan dua kalimat syahadat".

\footnotetext{
${ }^{16}$ Ngationo, Ana, 2018. Peranan Raden Fatah Dalam Mengembangkan Kerajaan Demak Pada Tahun 1478-1518. Jurnal Kalpataru 4, 1 (Juli 2018): 17-28.https://jurnal.univpgripalembang.ac.id/index.php/kalpa/article/view/2445
} 
Fungsi Masjid Agung Demak di hari Jum'at juga digunakan untuk sholat Jum'at berjamaah yang biasanya di imami oleh Sunan Ampel yang merupakan sunan tertua atau sesepuh dari para wali. Masjid Agung Demak ini merupakan cikal bakal bersatunya kaum muslim di tanah Jawa dibawah kepemimpinan Raden Fatah berdasarkan nasehat dari Sunan Kalijaga yang juga ahli dalam Ilmu Politik. Banyak para pedagang yang berlabuh dan singgah di wilayah pelabuhan Demak dan beramai-ramai bersilaturahmi terutama kepada para wali yang menjadi penasehat Kesultanan Demak. ${ }^{17}$

Sultan Fatah menerapkan strategi khusus melalui kekuasaan yag dimilikinya dalam rangka mensukseskan dakwah Islam, terutama ketika Sultan Fatah sudah mampu mengalahkan dan merebut Majapahit dari Girindra Wardhana. Dalam hal ini, Sultan Fatah membagi wilayah inti Kerajaan Majapahit sesuai hierarki pembagian wilayah negara bagian yang ada pada saat itu yang meliputi sembilan wilayah, yaitu: Trowulan, Daha, Blambangan, Mataram, Tumapel, Kahuripan, Lasem, Wengker, dan Pajang. Sultan Fatah mengirimkan para ulama ke sembilan wilayah dimaksud untuk menyebarkan dakwah Islam. Model dakwah yang diterapkan Sultan Fatah diawali dengan pengenalan ajaran Islam secara persuasif yang berorientasi pada penanaman aqiqah Islam yang disesuaikan dengan situasi dan kondisi yang ada. Para ulama-umara mengedepankan metode al-hikmat, yaitu kebijaksanaan yang diselenggarakan secara spektakuler sebagaimana yang dilakukan Sunan Kalijaga dengan pergelaran wayang dan gamelan sekatennya dimana syarat menontonnya adalah dengan mengucapkan dua kalimat syahdata (syahadatain). Kolaborasi ulama umara ini juga mampu menciptakan alat kemakmuran yang dapat melipatgandakan produksi ekonomi serta mempermudah hidup dan menghemat waktu. ${ }^{18}$

\section{E. SIMPULAN}

\footnotetext{
17 Pianto, Heru Arif, 2017. Keraton Demak Bintoro Membangun Tradisi Islam Maritim di Nusantara. $\begin{array}{lllll}\text { Jurnal SOSIOHUMANIORA } & 3, & 1 . & \text { (April } & 2017 \text { ): }\end{array}$ https://junal.ustjogja.ac.id/index.php/sosio/article/view/1521

${ }_{18}$ Farida, Umma, 2015. Islamisasi di Demak Abad XV M: Kolaborasi Dinamis Ulama Umara dalam Dakwah Islam di Demak. AT-TABSYIR: Jurnal Komunikasi Penyiaran Islam 3, 2 (Desember, 2015): 299318.https://moraref.kemenag.go.id/documents/article/97406410605864589
} 
Agama Islam datang ke Nusantara dibawah oleh ulama yang menumpang para pedagang asing dari beberapa negara didunia. Mereka berasal dari Turki, Arab, India, Cina, dan Gujarat. Para tokoh agama Islam ini banyak bermukim dibeberapa wilayah di Nusantara. Saat Kerajaan Majapahit berkuasa, kerajaan ini banyak menjalin kerja sama dengan negeri tetangga. Sehingga pada saat para ulama datang ke wilayah Majapahit mereka disambut dengan baik dan diberi kebebasan dalam mengajarkan ajaran Islam kepada masyarakat Majapahit. Agama Islam diajarkan dengan damai dan tanpa adanya paksaan. Berbagai aktivitas yang toleransi sering dilakukan ulama dalam kehidupan sehari-hari, sehingga banyak masyarakat yang tertarik untuk belajar agama Islam. Raden Fatah merupakan anak raja Brawijaya V penguasa Kerajaan Majapahit yang berasal dari istri keturunan Cina yang tinggal di Palembang. Setelah dewasa, Raden Fatah kembali ke Jawa dan berguru agama Islam dengan beberapa ulama di sana. Oleh Raja Brawijaya, Raden Fatah diberikan sebidang tanah untuk digunakan dengan sebaikbaiknya. Namun oleh Raden Fatah, tanah tersebut digunakan untuk membangun sebuah pesantren tempat belajar agama Islam.

Setelah melalui perjuangan yang sangat panjang dan didukung para ulama, sunan atau walisongo, akhirnya Raden Fatah mampu mendirikan Kerajaan Demak.pada saat berdirinya Kerajaan Demak, Kerajaan Majapahit sudah mulai hilang perannya dan akhirnya berhasil ditaklukan dalam peperangan. Perkembangan Kerajaan Demak mulai terlihat setelah Kerajaan Majapahit berlahan mulai redup kejayaannya. Bantuan para Walisongo sangat penting dalam berdirinya Kerajaan Islam Demak. Berdirinya Kerajaan Demak ini mengawali perjuangan penyebaran Islam ditanah Jawa. Untuk memudahkan masyarakat belajar agama Islam, akhirnya Raden Fatah bersama dengan para Walisongo sepakat mendirikan sebuah Masjid yang diberi nama Masjid Agung Demak. Fungsi Masjid Agung Demak ini sangat penting dalam memberikan pengaruh dalam penyebaran agama Islam. Sunan Kalijaga bersama walisongo lainnya dalam penyebaran agama Islam dengan menambilkan kesenian wayang kulit dan gamelan yang dimodifikasi secara Islam. Raden Fatah selaku Sultan Demak, melakukan menyerangan dibeberapa wilayah di Jawa sekaligus mengIslamkan masyarakatnya secara damai. Selain itu, Demak juga berperang melawan Portugis di Malaka sekaligus membendung pengaruh kristenisasi oleh Portugis.

\section{DAFTAR PUSTAKA}


Abdurrahman, Dudung, 2011. Metodologi Penelitian Sejarah Islam. Jakarta: Logos Wacana Ilmu.

Afifah, Nurul, 2018. Kepemimpinan Sultan Trenggana di Kerajaan Demak 1521-1546 Ditinjau Dengan Konsep Kepemimpinan Jawa HASTA BRATA. Yogyakarta: SKI UIN Sunan Kalijaga.

Basundoro, Purnawan, 2012. Pengantar Sejarah Kota. Yogyakarta: Ombak.

Darmawijaya, 2010. Kesultanan Islam Nusantara. Jakarta: Pustaka Al-Kautsar.

Farida, Umma, 2015. Islamisasi di Demak Abad XV M: Kolaborasi Dinamis Ulama Umara dalam Dakwah Islam di Demak. AT-TABSYIR: Jurnal Komunikasi Penyiaran Islam 3, 2 (Desember, 2015): 299318.https://moraref.kemenag.go.id/documents/article/97406410605864589

Gottschalk, 2008. Mengerti Sejarah. Jakarta: UI Press.

Haryanto, 2010. Kekuasaan Elit Suatu Bahasa Pengantar. Yogyakarta: Pascasarjana (S2) Politik dan Otonomi Daerah Bekerja sama dengan Jurusan Ilmu Pemerintahan Fisipol UGM.

Kartodirdjo, 2012. Pendekatan Ilmu Sosial Dalam Metodologi Sejarah. Yogyakarta: Ombak.

Lapian, A.B, 2010. Pelayaran dan Perniagaan Nusantara, Abad Ke-16 dan 17. Jakarta: Komunitas Bambu.

Ngationo, Ana, 2018. Peranan Raden Fatah Dalam Mengembangkan Kerajaan Demak Pada Tahun 1478-1518. Jurnal Kalpataru 4, 1 (Juli 2018): 1728.https://jurnal.univpgri-palembang.ac.id/index.php/kalpa/article/view/2445

Pianto, Heru Arif, 2017. Keraton Demak Bintoro Membangun Tradisi Islam Maritim di Nusantara. Jurnal SOSIOHUMANIORA 3, 1. (April 2017): 1826.https://junal.ustjogja.ac.id/index.php/sosio/article/view/1521

Purwasito, Andrik, 2015. Komunikasi Multikultural. Yogyakarta: Pustaka Pelajar. Yogyanto, R. Nurcahyo, 2017. Peran Raden Fatah Dalam Mengembangkan Agama Islam Di Demak Tahun 1478-1518. Yogyakarta: FKIP Pendidikan Sejarah UPY. 